\title{
Subject Status Test Code
}

National Cancer Institute

\section{Source}

National Cancer Institute. Subject Status Test Code. NCI Thesaurus. Code C117659.

A character or string that represents the short code name of the subject status assessment. 